
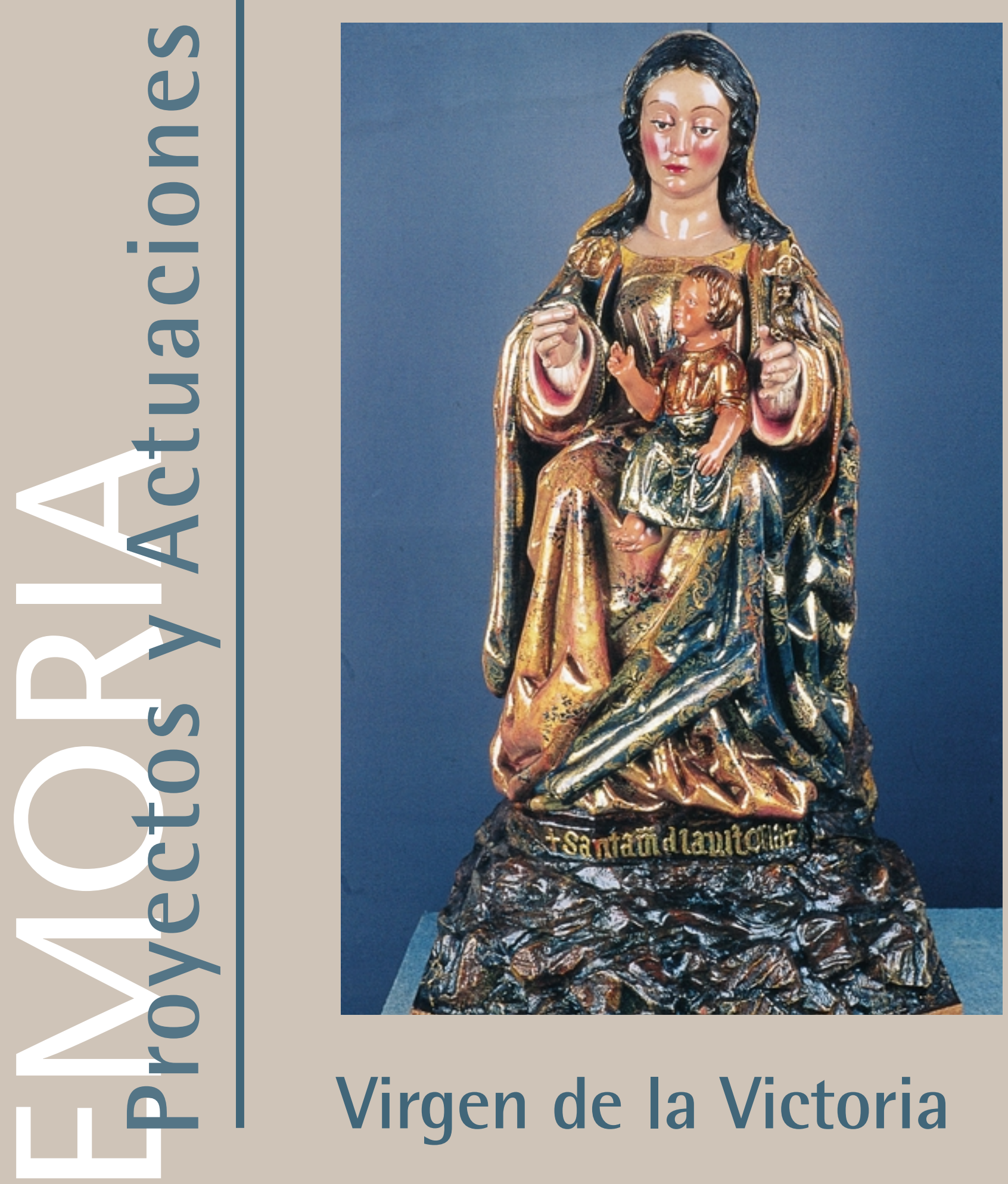

\title{
Virgen de la Victoria
}

Enrique Gutiérrez Carrasquilla

Eva Villanueva Romero

Eugenio Fernández Ruiz

Lourdes Martín García

Marta Sameño Puerto 
I. Virgen del Socorro, destruida. Teba (Málaga)

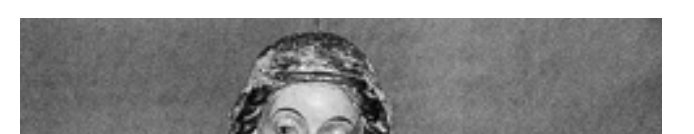

la victoria en Málaga atribuye el suceso a la Virgen y manda construir una ermita donde coloca una imagen de Nuestra Señora que traía en su campamento.

El otro religioso que cita la Virgen es el padre fray Lucas Montoya (1616) el cual, en su obra "Crónica General de la Orden de los Mínimos de San Francisco de Paula", dice que los Reyes tras conquistar Málaga mandaron construir una ermita con el nombre de Santa María de la Victoria y allí se colocó una imagen mariana que, según él, no se sabe si la traían los Monarcas con su ejército, si la mandaron hacer, o si fue un regalo del emperador Maximiliano de Austria.

Posteriormente, ya en el siglo XIX, Guillén Robles ( I874) en su obra "História de Málaga y su provincia", cuenta que según la tradición los conquistadores cristianos llevaban consigo una imagen de la Virgen que recibía culto en el campamento.

Este mismo autor en 1880 en su libro "Málaga musulmana" refiere que estando los Reyes en el cerco de Málaga llegaron a la costa dos embarcaciones enviadas por el emperador Maximiliano de Austria, y que en ellas traían varias piezas de bronce, campanas para ponerlas en las poblaciones que se fueran conquistando, y gran cantidad de pólvora, herreros y artilleros. Pero no hace referencia a que trajesen ninguna imagen.

\section{ESTUDIO HISTÓRICO ARTÍSTICO}

La imagen de la Virgen de la Victoria está íntimamente relacionada con la conquista de Málaga por los Reyes Católicos ocurrida en 1487, y con la fundación, también en esta ciudad, del primer convento de franciscanos mínimos de Andalucía en el año 1495.

Su origen y autoría no están del todo claro existiendo varias opiniones a través de la história al respecto. Según la tradición fue una de las ofrendas enviadas a los Reyes Católicos por el emperador Maximiliano de Austria durante el cerco de Málaga, y recibió culto en el oratorio del campamento del rey Fernando hasta que una vez conquistada la ciudad los monarcas mandan construir una ermita en el mismo lugar donde estuvo la tienda de campaña del rey, y allí depositan la imagen.

Pero no se tienen datos que confirmen que la Virgen fue un regalo del emperador Maximiliano, ya que entre las fuentes de la época que tratan sobre la conquista de la ciudad, como las "Crónicas de los Reyes Católicos" escritas por Fernando del Pulgar en el siglo XV, solo se refiere que "enbio al rey ciertas lombardas e tiros de polvora, con todos los aparejos que eran necesarios" pero no se cita ninguna escultura.

Las referencias documentales más antiguas acerca de la imagen son confusas, datan del siglo XVII y la recogen dos franciscanos mínimos que escriben sobre la fundación de su orden, uno de ellos es el padre Juan de Morales (1619), quien en su obra "Epítome de la fundación de la Provincia de Andalucía de la Orden de los Mínimos", comenta que el rey tras haber con-
Sin embargo Joaquín Díaz de Escobar (1898) en su estudio sobre la Virgen titulado "La imagen de la Virgen de la Victoria, patrona de Málaga" cuenta también la llegada de estos barcos y añade que además de campanas mandaron imágenes para darles culto en los templos que fueran construyendo en las poblaciones conquistadas.

Con respecto a la ermita de Santa María de la Victoria se conoce con certeza su existencia ya que en 1493 mediante Real Cédula los Reyes Católicos la donaron a la orden de los mínimos, aunque no se sabe con exactitud cuál fue su ubicación.(I)

Estos frailes menores se hacen cargo de ella desde I 495 mediante Provisión Real y fundan el primer convento de su orden en Andalucía tomando como patrona a la Virgen de la Victoria.

Posteriormente en 1518 se consagra un nuevo templo dedicado también a esta advocación mariana, y es entonces cuando se traslada en procesión a esta iglesia.

Acerca de su autoría tampoco se ponen de acuerdo los distintos investigadores que en nuestro siglo la han estudiado, entre ellos Juan Temboury (1966) quien opina que la Virgen pudo ser realizada por un escultor llamado Juan de Figueroa, que al parecer acompañó a los Reyes en su séquito durante la conquista, pero del cual se tienen muy pocos datos.

Por otro lado, Agustín Clavijo García (1984) dice que pudo ser realizada por algún escultor del círculo de 
Lorenzo Mercadante de Bretaña que trabajó en Sevilla en el segundo tercio del siglo XV y compara la Virgen de la Victoria con la desaparecida Virgen del Socorro del pueblo de Teba, fechada hacia I500. (Foto I)

El historiador José Luis Romero Torres (1984) comenta que los rasgos estilísticos de la Virgen muestran similitudes con la obra del escultor Jorge Fernández Alemán, que se sabe trabajó en Sevilla en el retablo mayor de la catedral, y la compara en concreto con la Virgen sedente de la escena de la Epifanía de este retablo. (Foto 2)

Además de establecer el encuadre histórico de la obra y revisar sus supuestas autorías, la intervenciónrestauración ha permitido también realizar un estudio comparativo con otras imágenes pertenecientes a la misma época y relacionadas con los Reyes Católicos. Entre ellas se encuentra una escultura de San Roque que actualmente no se conserva pero que sabemos estuvo en el Santuario de la Victoria. (Foto 3)

En esta obra podemos observar unos rasgos o grafismos semejantes a los de la Virgen de la Victoria.

La imagen de San Roque según el padre fray Lucas Montoya (1616) fue donada por los Reyes Católicos. Al parecer hacia 1494 la ciudad sufrió una epidemia de peste por lo que siendo San Roque abogado de esta enfermedad, es lógico que se crease una ermita dedicada al santo donde se veneraba esta imagen.

Aunque la tradición cuenta que en esta ermita estuvo la Virgen de la Victoria antes de ser trasladada a la iglesia del convento, no consta documentalmente.

Lo que sí se conoce con certeza es que la imagen de San Roque se depositaría en 1835 con motivo de la desamortización en el Santuario de la Victoria, quedando entonces la ermita sin culto.

Con respecto a las modificaciones y restauraciones que ha sufrido la obra, en el proceso de restauración llevado a cabo en el Instituto Andaluz del Patrimonio Histórico, se ha confirmado por medio de los datos técnicos lo que ya conocíamos a través de la documentación histórica y por otro lado ha aportado datos nuevos.

Entre los cambios que hemos podido constatar documentalmente está el que se le realizó en la peana, y es en concreto la sustitución de la inscripción original que tenía por la que tiene actualmente. Juan de Morales (1616) en su obra citada anteriormente, describe a la Virgen sentada sobre una peña donde tiene la siguiente inscripción en latín: "SANTA MARIA DE LA VICTORIA. QUI VIDI TESTIMONIUM PERHIBEO", (Santa María de la Victoria. Yo que ví he dado testimonio). Esto podría referirse a la leyenda que cuenta que unos días antes de la conquista de Málaga el rey tuvo un sueño en el que se le apareció la Virgen con una palma en la mano, símbolo de la Victoria.

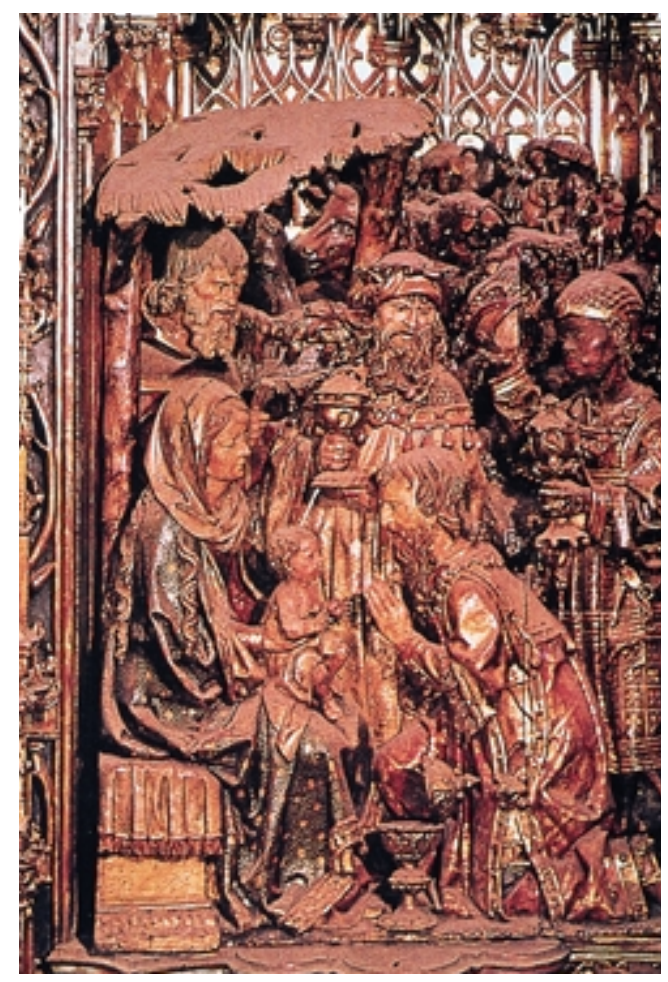

$\frac{⿱ 亠}{a r}$

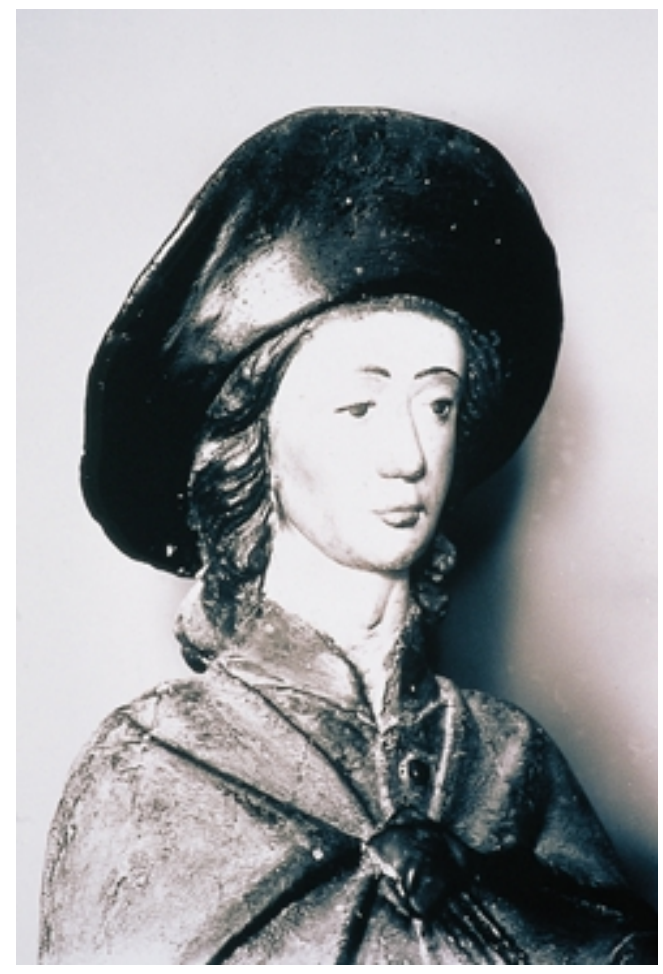

2. Escena de la Epifanía de Retablo Mayor de la Catedral de Sevilla.

3. Imagen de San Roque, desaparecida, que perteneció al Santuario de la Victoria.
Mientras que ya a finales del siglo XVIII, García de la Leña (1792) en sus "Conversaciones históricas malagueñas", escribe también que está sentada en una piedra pero que la inscripción es solamente: "SANTA MARÍA DE LA VICTORIA".

También debieron modificarse los cabellos de la Virgen, ya que según describe Joaquín Díaz de Escobar ( 1898 ), la imagen tenía el cabello rubio, característica 


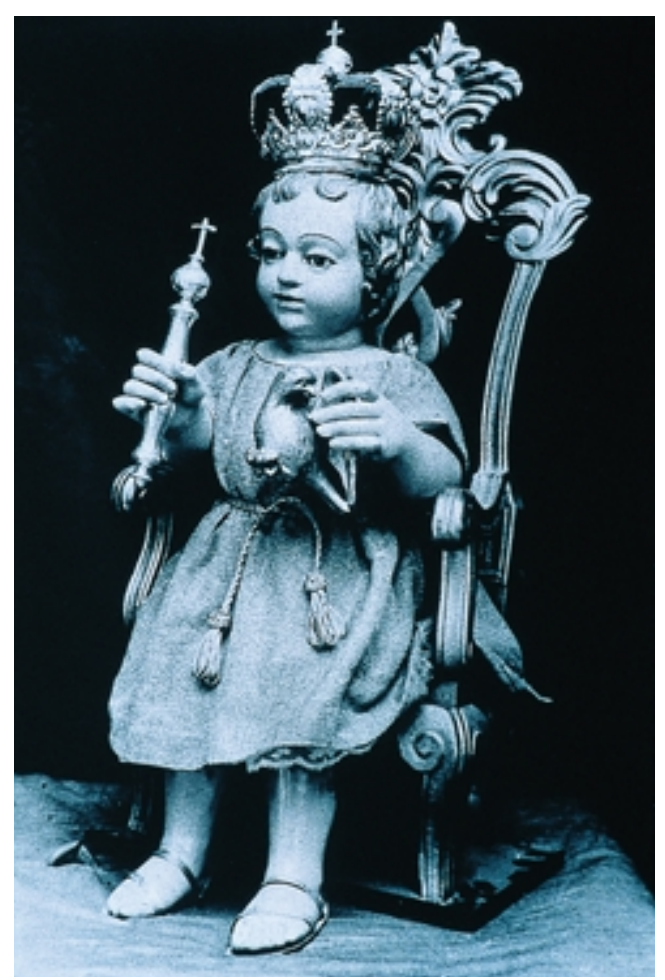

4. Imagen del Niño Jesús anterior al ejecutado por Adrián Risueño. de las vírgenes de la época. Lo cual hemos podido confirmar durante la resturación al percibirse dorado debajo de los cabellos actuales. Además, por una señal que tiene en el pelo creemos que pudo tener la toca más hacia delante, por lo tanto los mechones que le caen a ambos lados sobre los hombros probablemente no son originales sino añadidos que cubren la toca primitiva.

Juan Temboury (1943) en una obra sin publicar titulada "História verdadera de la patrona de Málaga", hace referencia a que la imagen ha sido intervenida en varias ocasiones, fechando la primera de ellas antes de 1792. (2)

Según este autor antes de esta fecha además de haberle sido escofinado el letrero primitivo de la peana para colocarle el actual, la escultura también había sufrido otras restauraciones que consistieron en colocarle nuevas manos y repolicromarle sus vestimentas.

Refiere así mismo que para adaptarla a una tradición que habla de su milagrosa aparición sobre unos riscos del campo de batalla, sería cercenado el respaldo del sillón donde estuvo sentada originariamente, teniéndole que añadir una tabla de caoba sobre la cual por medio de telas encoladas se formaban los pliegues del manto. La existencia de esta tabla se ha podido constatar, por medio de radiografías y visualmente en la parte posterior de la escultura habiendose localizado en ella dos tipos de clavos unos antiguos probablemente de la época en la que se colocó, y otros más modernos.

Además, por medio de la intervención, hemos podido comprobar através de una abertura efectuada en la parte posterior de la escultura, que la imagen es hueca por dentro, posiblemente porque en un principio fue concebida para estar ubicada en un retablo, por lo que la tabla de caoba debió añadírsele a partir de 1700, fecha en que es colocada en el camarín, para convertirla en una imagen de bulto redondo. (3)

Al mismo tiempo se ha observado que la Virgen en su origen carecía de peana, posteriormente se le añade una peana pequeña que finalmente se recrece en la restauración que se lleva a cabo en 1943.

El historiador Manuel Gómez Moreno añade al texto de Temboury (1943) que el rostro de la Virgen, las manos y el pelo tuvieron que ser rehechos en el siglo XVIII y además poseía tallada corona de madera. Este último dato también ha podido ser verificado al descubrirse durante la intervención que la escultura conserva unos huecos a los lados de la cabeza que podría ser el lugar donde encajaba esta corona, cuya marca se puede observar también por medio de las radiografías realizadas a la obra.

Hacia I86 I sería restaurada de nuevo la Virgen, según Temboury (1943), por Diego Gutiérrez de Toro, escultor malagueño que trabaja en esta ciudad durante la segunda mitad del XIX, el cual le reparó las partes apolilladas y los desperfectos de la policromía. Este mismo escultor le quita el Niño que poseía sujeto a la falda por un perno de hierro, y lo hace exento articulandole la cintura y las rodillas para sentarlo en un trono o sillita delante de Ella y a los pies. Este Niño se sigue conservando actualmente, aunque creemos que no es el original ya que tuvo otro anteriormente. (Foto 4)

La última restauración que comenta este mismo investigador es la que hace en 1943 Adrián Risueño, escultor malagueño de la primera mitad del siglo XX, creándole completamente nuevo el Niño que actualmente posee.

También es probable que en este momento se llevase a cabo el recrecimiento de la peana antes comentado, y que además este escultor interviniese en la parte posterior de la escultura al localizarse en la tabla de caoba unos clavos de factura moderna.

De esta intervención encontramos, cuando se separó el Niño de la Virgen, una página de un periódico local haciendo la función de relleno, fechada el día dos de febrero de 1943, seis días antes de la coronación de la Virgen.

A esto hay que añadir que por medio de la limpieza de cierta zona de la escultura, se ha podido reconocer como el escote de la túnica de la Virgen originariamente era más cerrado por los lados, lo que estaría más acorde con la vestimenta que se utilizaba para las imágenes de esa época.

A parte de estas restauraciones se tienen otros datos, a través de grabados, de que desde fines del siglo XVII se revestía a la Virgen con una serie de vestimentas. Incluso la reina Isabel II después de su viaje a Málaga en 1862 le envió como ofrenda un manto y un vestido.

Al parecer, se le continuó vistiendo hasta los años 30 del siglo XX aproximadamente, momento en que Temboury descubre que es una imagen tallada de cuerpo entero y de gran calidad artística por lo que propone a la hermandad que se le deje de revestir, aunque es posible que en ocasiones especiales se le siguiera colocando un manto. (Foto 5)

Por otra parte mediante los análisis químicos de pigmentos realizados con muestras extraídas en determinadas zonas de la escultura, se ha podido comprobar que en general presenta dos capas de policromía con sus respectivos estratos, tanto en el rostro como en las vestimentas de la Virgen, correspondiendo la 
última capa con el estilo dieciochesco de la decoración y ornamentación de la túnica y el manto.

Los resultados obtenidos en estos análisis han aportado la existencia de "azul de Prusia" entre los pigmentos analizados de una muestra extraída de la parte posterior del manto. Este tipo de pigmento empieza a usarse en Andalucía a partir de la segunda mitad del siglo XVIII, lo que coincide con la restauración que Temboury fecha antes de 1792.

Así mismo se han realizado análisis de la madera, cuyos resultados han permitido conocer que la escultura está tallada en madera de álamo, en concreto de álamo blanco. Este tipo de madera ha venido empleándose tradicionalmente por los imagineros andaluces. (4)

En conclusión creemos que la imagen de la Virgen de la Victoria fue realizada una vez conquistada la ciudad de Málaga, entre finales del siglo XV o principios del $X V I$, habiendo sido transformada posteriormente en varias ocasiones, por las siguientes razones:

- Porque a través de las fuentes documentales tenemos datos de la donación mediante Cédula Real de una ermita con el nombre de Santa María de la Victoria a la orden de los mínimos en 1493, y que en esta ermita se veneraba una imagen de la Virgen.

- Por su parecido estilístico con imágenes marianas de la época y especialmente con la escultura de San Roque, anteriormente citado, relacionada también con los monarcas.

- Porque el tipo de madera de álamo blanco, en que está tallada se emplea frecuentemente en Andalucía.

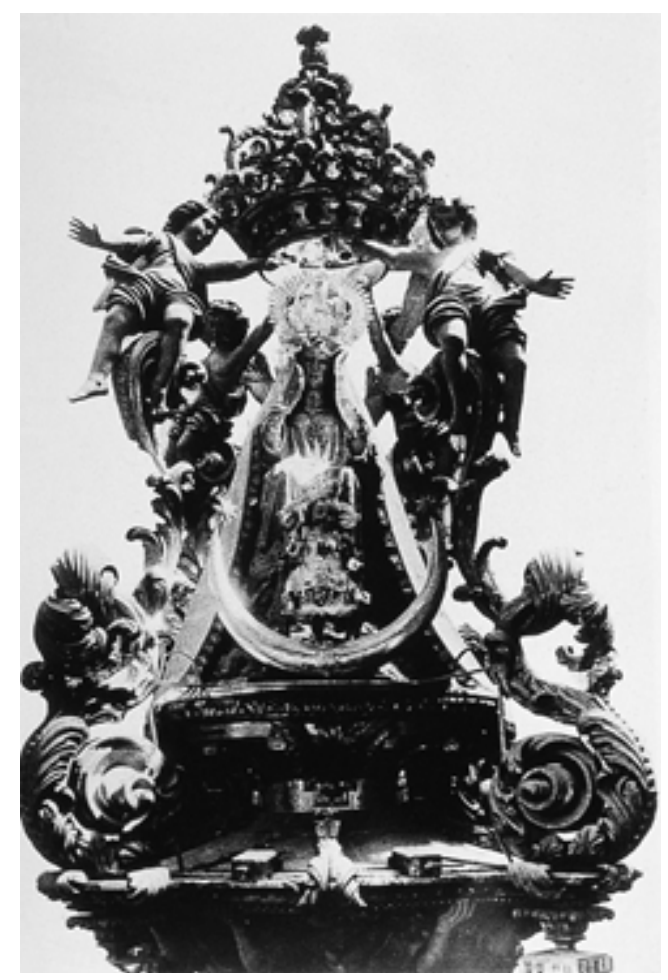

5. Virgen de la Victoria hacia 1930.
- Y por último porque el tamaño de la Virgen es mayor que el de las imágenes que en esta época solían llevar los Reyes en los oratorios de las tiendas de campaña, y además porque es una escultura creada en principio para estar ubicada en un retablo. Por lo que es más probable que la imagen que citan las fuentes documentales que traían los monarcas en su campamento, fuera la Virgen de los Reyes (actualmente en la Catedral), de menor tamaño, realizada también por esta época y no la obra recientemente restaurada.

\section{Notas}

I. Este documento lo recoge el padre Juan de Morales en su obra "Epítome de la fundación de la Provincia de Andalucía de la orden de los mínimos". Málaga, 1619. P. 366.

2. La obra citada se encuentra en la colección de carpetas del Archivo Temboury, en la biblioteca Cánovas del Castillo de la Diputación de Málaga.
3. La Virgen de la Victoria aparece representada en la hornacina central del retablo mayor del Santuario de la Victoria en un grabado de 169| que reproduce Clavijo García en su obra "La imagen de la Virgen de la Victoría y sus variaciones iconográficas". Málaga, 1984. Lámina III

4. Sánchez-Mesa, D.: Técnica de la escultura policromada granadina. Granada, 197I.P. 29

\section{Bibliografía}

CAMACHO MARTÍNEZ, R.: La emblemática y la mística en el Santuario de la Victoria en Málaga. Málaga, 1986.

CLAVIIO GARCÍA, A.: La imagen de la Virgen de la Victoria y sus variaciones iconográficas. Carpeta de grabados e ilustraciones. Málaga, 1984.

DÍAZ ESCOBAR, J.: La imagen de Nuestra Señora de la Victoria. Patrona de Málaga. Estudio histórico. Málaga, 1898

GARCÍA DE LA LEÑA, C.: Conversaciones históricas malagueñas. 4 vols. Impreso por la Caja de Ahorros de Málaga, 1982.

GUILLÉN ROBLES, F.: Málaga musulmana. Málaga, 1880.

GUILLÉN ROBLES, F.: História de Málaga y su provincia. Málaga, 1991. (3a ed.)

MONTOYA, P. F. L.: Crónica general de la orden de los mínimos de san Francisco de Paula, su fundación. Donde se trata de su vida y milagros, origen de la religión, erección de provincias y varones insignes de ella. Por el predicador y cronista de la Orden en la provincia de Castilla. En Madrid por Bernardino de Guzmán. Año 1619.

MORALES, P. J. de : Epítome / de la Fundación / de la Provincia de Andalucía / de la Orden de los Mínimos, ed. por Juan René. Málaga, 1619.

PULGAR, F. DE: Crónica de los Reyes Católicos. Valencia. Imprenta de Benito Monfort, año de 1780 .

ROMERO TORRES, J. L.: "La escultura de los siglos XV al XVIII". Málaga. T. III (Arte). Colección Nuestra Andalucía. Granada, 1984.

SÁNCHEZ-MESA, D.: Técnica de la escultura policromada granadina. Granada, 1971.

TEMBOURY ALVÁREZ, l.: História verdadera de la patrona de Málaga. Málaga, 1943. (Sin publicar).

TEMBOURY ALVÁREZ, J.: Informes histórico-artísticos de Málaga. Málaga, 1966.

V.V. A.A.: Guía histórico-artística de Málaga. Málaga, 1992. 


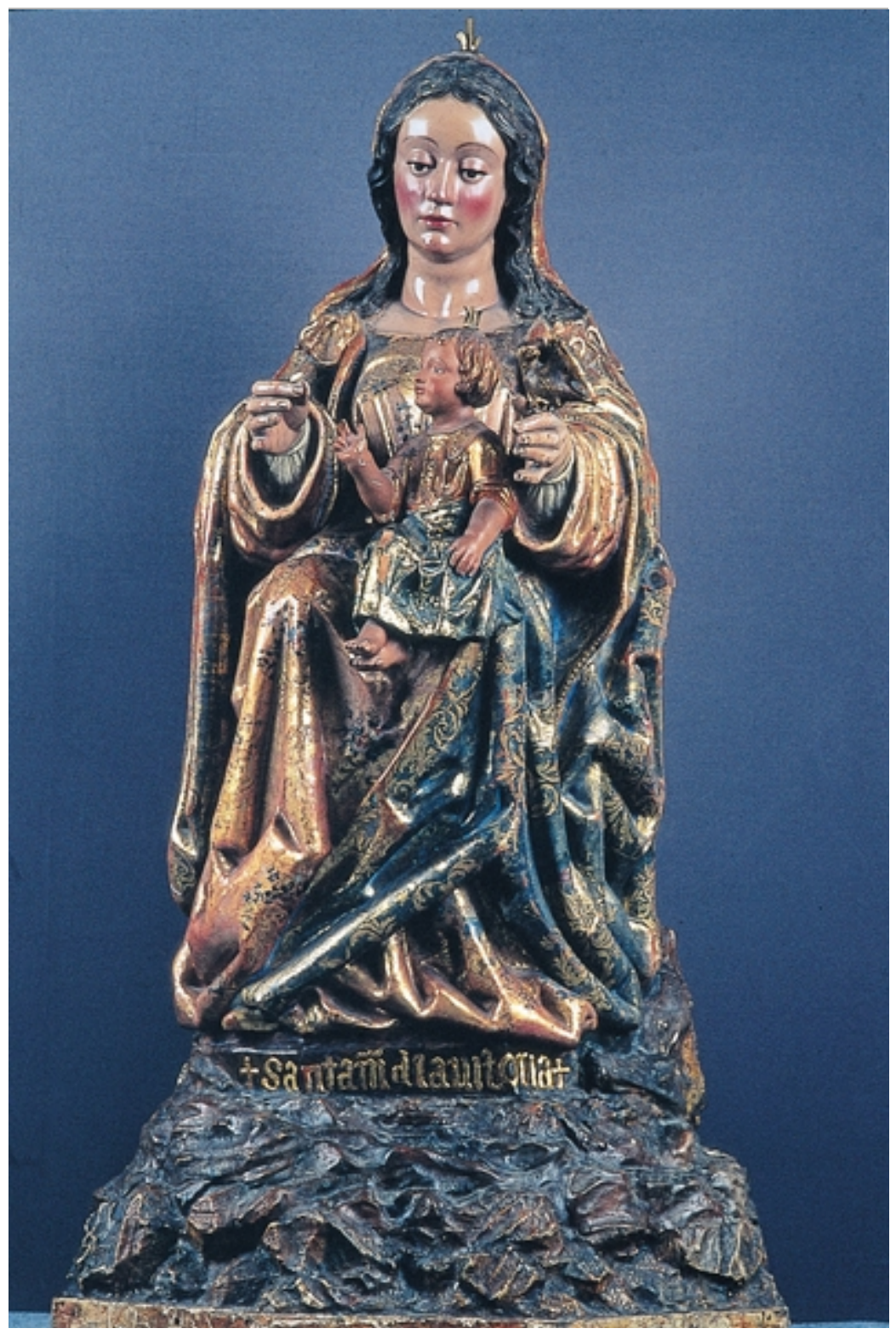

Estado inicial de obra.

\section{DATOS TÉCNICOS DE LA OBRA}

La imagen de Santa María de la Victoria, es una escultura en madera policromada, en la que podemos encontrar datos muy significativos de lo que es una obra alterada y modificada a lo largo de su dilatada historia material.

Estas modificaciones han sido tanto morfológicas como cromáticas, y a todos los niveles, desde el soporte al estrato superficial.

Los estudios técnicos, estudio radiográfico, análisis de pigmentos, estudio estratigráfico y de correspondencia, y el tratamiento en sí realizados sobre la imagen, nos han llevado a diferentes conclusiones.

En origen se trataba de una escultura, posiblemente de retablo, ya que no está rematada por la parte posterior, ahuecada desde la base hasta la zona coincidente con el inicio del cuello, con corona tallada sobre la cabeza y sin peana, sirviendo como base, bajo los pies, una estrecha franja, tallada en el mismo bloque que la imagen, sobre la que existe una inscripción. La posición original del Niño no se ha podido definir.

Cromáticamente presentaba, encarnadura en rostro y manos, túnica, corona y cabellos dorados, manto en tonos azules y toca en gris claro.

Actualmente presenta morfología de escultura de bulto redondo, rematada por la parte posterior con una tapa de madera de caoba, sobre la que se han construido pliegues del manto con telas encoladas.

Bajo la base original se han construido, en diferentes épocas, dos peanas que representan sendos montículos de piedras, el último de los cuales descansa sobre una franja lisa que bordea todo el contorno. Se ha eliminado la corona, y las manos son móviles, sujetas al brazo por una espiga de madera. Parte de la toca, que caía sobre los hombros se había retallado convirtiéndola en cabello. El Niño descansa sobre la rodilla izquierda de la Virgen.

Cromáticamente, el rostro y las manos siguen en tonos de encarnadura, la túnica se ha dorado y estofado en tonos rosas, el manto en azul y la toca en blanco. El cabello presenta tonos marrones así como la peana.

\section{Estudio científico-analítico}

Para el exacto conocimiento, tanto de la técnica empleada para su ejecución, como de la patología que presentaba, han sido necesarios la realización de una serie de estudio preliminares, los cuales a su vez nos aportaron datos fundamentales para la ejecución del tratamiento.

\section{Métodos físicos de examen}

Tienen por objeto conocer aspectos de la obra que no son visibles al ojo humano y que nos aportan información de la estructura interna y externa.

Dentro de este grupo se ha efectuado un estudio radiográfico con las siguientes tomas:

- Toma radiográfica general antero-posterior.

- Toma radiográfica general lateral.

De igual forma se ha realizado un examen con luz ultravioleta de la totalidad de la imagen, así como la correspondiente documentación fotográfica con luz normal.

\section{Estudio analítico}

Se tomaron un total de doce muestras, once correspondientes a la policromía y una de tejido para la identificación de soporte en la zona reconstruida 
con telas encoladas. Los fragmentos de pintura se englobaron en metacrilato y se cortaron perpendicularmente para obtener la sección transversal. En estas secciones se analizaron tanto la capa de preparación como las capas de pintura. En cuanto al tejido, se realizó la preparación, tanto de la sección transversal como la longitudinal, para la identificación de las fibras textiles.

Para la identificación del tipo de madera del soporte se analizaron un total de 8 muestras.

\section{Estudio de correspondencia}

El estudio de correspondencia, mediante 45 microcatas analizadas con lupa prismática binocular, determinaron: $\mathrm{n}^{\circ}$ de superposiciones polícromas $y / 0$ repintes(parciales o totales), extensión, estado de conservación, así como la correspondencia existente entre ellas.

\section{Soporte}

Actualmente, en la imagen se pueden diferenciar tres zonas:

I. Parte que se conserva de original, tallada sobre una sola pieza de madera y ahuecada en su interior desde la base hasta la zona correspondiente con el cuello.

2. Parte posterior y primera peana, construida en telas encoladas (para el manto) y trozos de madera(para el risco), sobre una tapa de madera unida a la imagen por medio de clavos de forja.

3. Segunda peana, construida sobre una estructura hueca de madera, en la cual a ambos lados, se practicaron sendos orificios, bordeados por una pletina metálica, a través de los cuales se introducían los pernos de sujeción al trono procesional.

En algunas zonas se han encontrado restos de lienzo sobre la madera, supuestamente para reforzar zonas agrietadas.

Las manos son piezas independientes, unidas al brazo por medio de una espiga de madera que se introduce en el hueco practicado en este y atravesadas por una varilla metálica para impedir su salida accidentalmente.

El Niño que es de factura reciente, estaba unido a la rodilla izquierda de la Virgen, por medio de una espiga de madera encolada y un tornillo metálico.

Tanto la Virgen como el Niño, presentaban en la cabeza una pieza metálica con rosca, para sujeción de la corona, y una pletina del mismo material sujeta con cuatro pequeños tornillos a los dedos índice y pulgar de la mano derecha de la Virgen, para sujeción del cetro.
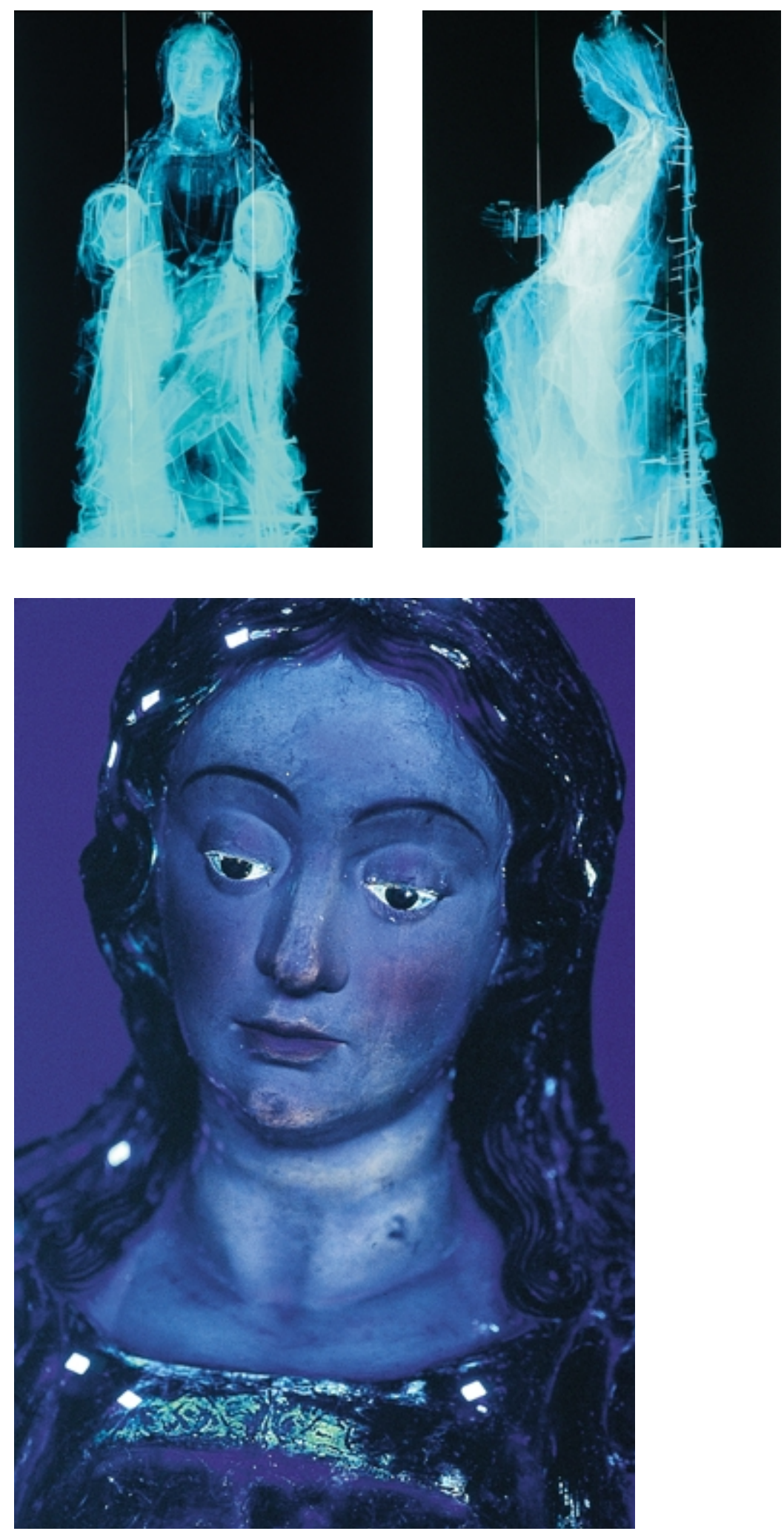

Tomas radiográficas antero-posterior y lateral.

\section{Tipo de soporte}

Para la identificación del tipo de soporte, se tomaron muestras de pequeño tamaño y en aquellos lugares donde éste quedaba al descubierto y su extracción no dañaba la integridad de ningún estrato. Para ello se tubo en cuenta las tres caras en las que se han de
Detalle de la cabeza con iluminación ultravioleta. Se aprecian repintes significativos en los laterales del escote de la túnica. 
$\frac{\pi}{0}$
$\sum$
$\sum$
$\Sigma$

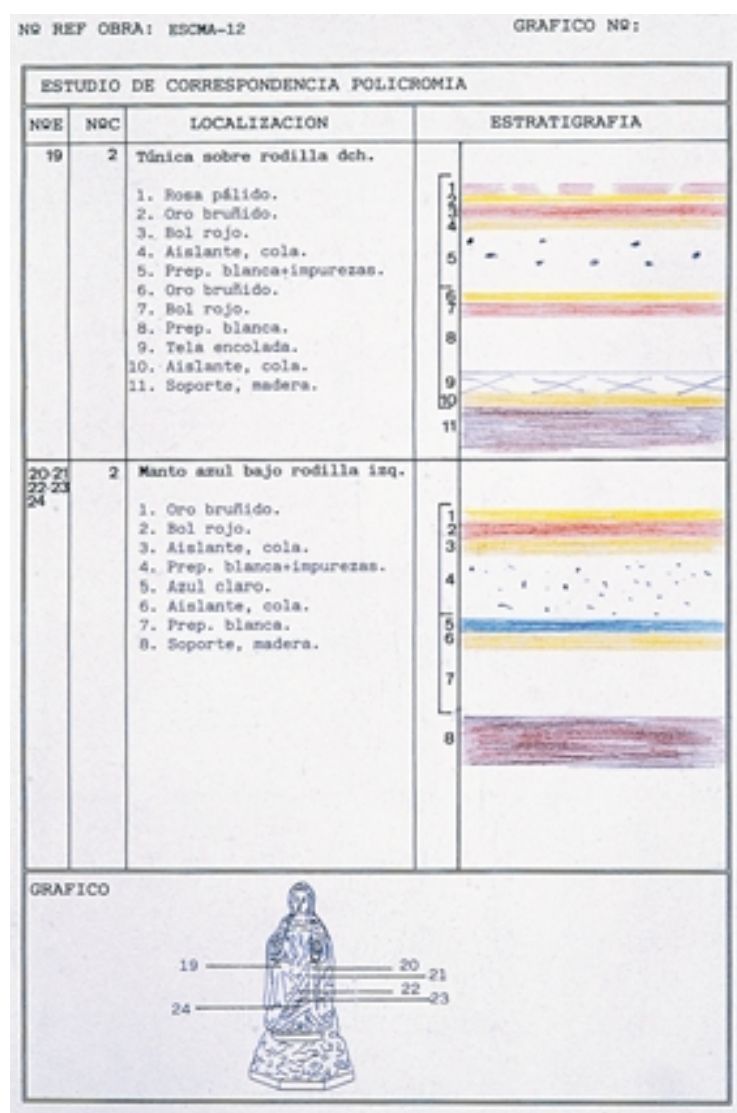

Ficha técnica resultante del estudio de correspondencia.

Reconstrucción gráfica del estado original de la imagen, antes de la intervención del s.XVIII. realizar los tres cortes (radial, tangencial y transversal) para su correcta identificación.

\section{Metodología de trabajo para la identificación de muestras:}

I. Localización de muestras. Se extrajeron un total de ocho muestras localizadas en:

I. Primera peana

2. Segunda peana

3. Interior brazo derecho

4. Interior brazo izquierdo

5. Espiga de la mano derecha

6. Parte superior de la cabeza

7. Hueco interior

8. Tabla de cierre del hueco interior

2. Observación previa de la muestra al estereomicroscopio (lupa binocular).

3. Preparación de la muestra, para facilitar los cortes de las distintas secciones.

4. Observación de la muestra, de nuevo, al estereomicroscopio y realización de cortes, mediante bisturí.

5. Observación al microscopio óptico con luz transmitida, de las distintas secciones.

6. Resultados,

Muestra $n^{\circ}$ I. Especie: Ulmus campestris L., scabra Mill.,U. Laevis Pallas.

Familia: Ulmaceae.

Nombre común: Olmo.

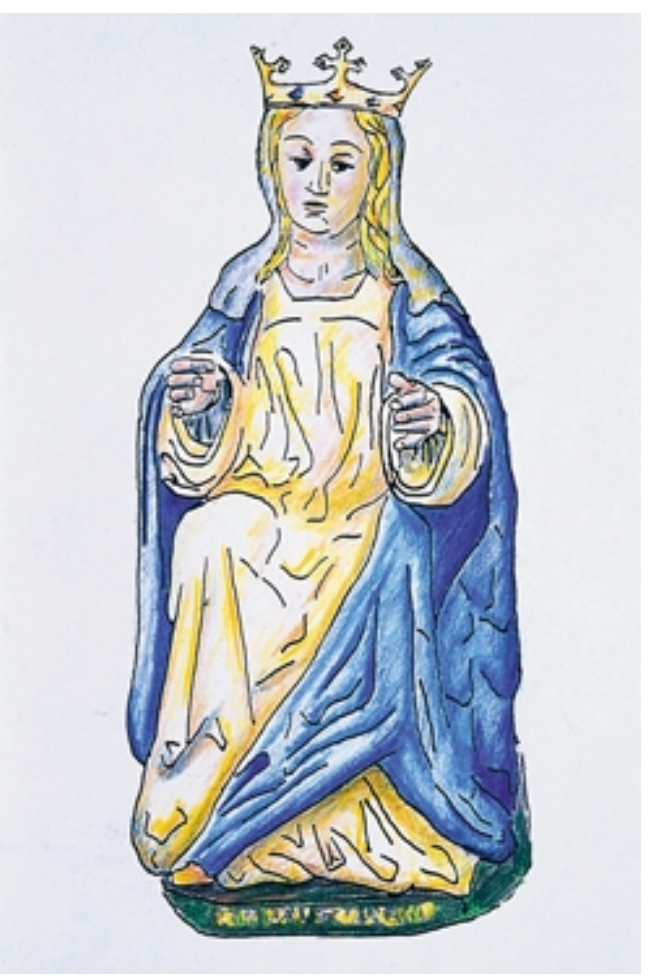

Muestra $n^{\circ} 2 . \quad$ Especie: Pinus silvestris $L$. Familia: Pinaceae

Nombre común: Pino silvestre

Muestra $n^{\circ}$ 3. Especie: Populus tremula L.,

P. Alba L., P. Nigra L.

Familia: Salicaceae

Nombre común: Alamo,

álamo blanco, chopo.

Muestra $n^{\circ} 4 . \quad$ Especie: Populus tremula L., P. Alba L., P. Nigra L.

Familia: Salicaceae

Nombre común: Alamo,

álamo blanco, chopo.

Muestra n ${ }^{\circ}$. Especie: Prunus avium L.

Familia: Rosaceae.

Nombre común: Cerezo

Muestra ${ }^{\circ}$ 6. Especie: Populus tremula L., P. Alba L., P. Nigra L.

Familia: Salicaceae

Nombre común: Alamo,

álamo blanco, chopo.

Muestra $n^{\circ} 7 . \quad$ Especie: Populus tremula L., P. Alba L., P. Nigra L.

Familia: Salicaceae

Nombre común: Alamo,

álamo blanco, chopo.

Muestra $n^{\circ} 8 . \quad$ Especie: swietenia macrophylla

Familia: Meliaceae

Nombre común: caoba.

\section{Preparación y policromía}

Para el perfecto conocimiento y posterior tratamiento de estos estratos nos servimos de los datos aportados por los estudios previos que aclararon de forma definitiva la historia material de la imagen: 
- Estudio radiográfico. Principalmente nos desveló el porcentaje de encarnadura original en el rostro y cuello, y las modificaciones llevadas a cabo en el reborde de la túnica en su unión con el cuello.

- Estudio analítico y de correspondencia. Se determinaron las diferentes capas de policromía y se reconstruyó, con exactitud, el primitivo aspecto polícromo de la obra.

Al ser ésta una imagen repolicromada, presenta distintas capas de preparación, todas ellas magras. La aplicada directamente sobre el soporte, que sería la original, y la aplicada para las distintas superposiciones y modificaciones de la capa de color.

Así tendríamos que la aplicada en primer lugar, es decir directamente sobre el soporte, es de color blanquecino, constituida por sulfato cálcico aglutinado en cola animal y un espesor grueso $(>3 \mid 5 \mu)$.

La superpuesta a la primera policromía es de iguales características que la anterior y su espesor oscila entre 280 y $310 \mu$.

En las zonas nuevas, como son la parte posterior y la segunda peana, se han localizado estratos de preparación cuya composición es a base de carbonato cálcico, con espesores que oscilan entre 190 y $220 \mu$.

Sobre esta capa de preparación, se superpone, en las zonas de encarnadura de la Virgen, una de imprimación de blanco de plomo y minio.

Las zonas de dorado, se completan con una fina capa de bol rojo previa aplicación de la lámina de oro.

La visión cromática de la imagen corresponde a la policromía aplicada en el siglo XVIII.

Esta consiste, en la zona de los ropajes, en un estofado sobre dorado con panes de oro fino, realizado con la técnica del rallado, decorado posteriormente a punta de pincel y cincelado en las zonas visibles de oro.

La túnica de la Virgen presenta estofado en tonos rosas y rojos, y el manto en azul oscuro.

La encarnadura, ejecutada al óleo pulido, presenta una tonalidad pálida rosácea con matices en los pómulos.

El cabello es de color marrón, así como el risco sobre el que descansa.

Los ropajes del Niño son igualmente estofados sobre oro fino, rojos en la túnica y verde en el manto. La encarnadura, ejecutada al óleo poco pulida, esta entonada en colores ocres de tonalidad cálida, totalmente diferente a la de la Virgen.

Los espesores de las diferentes policromías es muy variable oscilando entre las 25 y $95 \mu$.

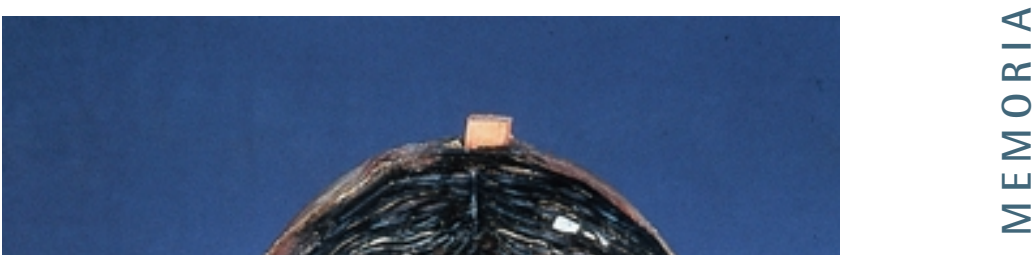

\section{Análisis efectuados} donde una vez eliminados los depósitos superficiales, aparece el cromatismo real de la imagen.

- Examen preliminar con la lupa binocular

- Observación al microscopio óptico con luz reflejada de la sección transversal (estratigrafía)

- Microanálisis (EDAX) de la sección transversal

- Análisis microquímico de cargas y pigmentos

- Estudio de la sección transversal y longitudinal de las fibras, lavadas y decoloradas, al microscopio óptico.

\section{Localización de las muestras}

V-I Carnación; mano derecha, base del pulgar

V-2 Carnación; mano izquierda, dedo meñique

V-3 Carnación; antebrazo del Niño

V-4 Blanquecino; pliegue de la túnica de la Virgen

VV-5 Azul; manto de la Virgen

VV-6 Azul; manto de la Virgen, parte trasera

WV-7 Blanco; toca de la Virgen

V-8 Marrón; cabellos

V-9 Carnación; cuello

VV-10 Marrón; peana

VV-I I Azul grisáceo; por debajo de la policromía superior

V-12 Tejido debajo de la policromía; espalda 


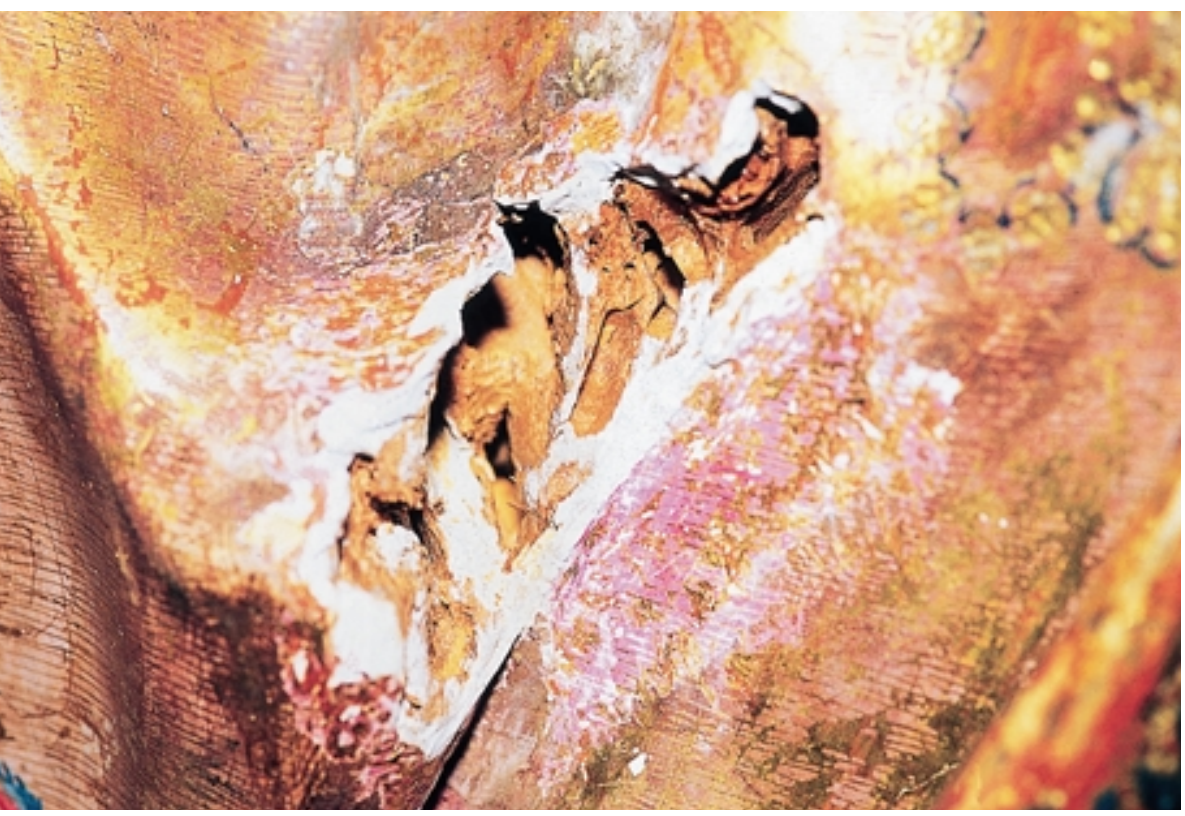

Orificios de salida insectos, produciendo graves pérdidas de soporte.

\section{Discusión de resultados}

La preparación está compuesta por sulfato cálcico y cola animal. En la parte trasera de la imagen y en la peana se ha encontrado, en la policromía más externa, una preparación compuesta por carbonato cálcico y cola.

El tejido que está debajo de la policromía se ha comprobado que es de lino.

La carnación de la Virgen esta compuesta por los siguientes estratos:

- Capa de preparación, de sulfato cálcico

- Capa de cola aislante

- Imprimación, a base de blanco de plomo mezclada con algunos granos gruesos de minio

- Capa de color, formada por blanco de plomo, bermellón y tierra roja

En la muestra correspondiente al cuello se han encontrado restos de una policromía anterior, compuesta esencialmente por blanco de plomo.

En la carnación del Niño se han encontrado, al menos, dos policromías: la más antigua presenta una capa de preparación, de sulfato cálcico y una capa rojiza compuesta, fundamentalmente, por tierra roja. Después encontramos una nueva capa de preparación, también de sulfato cálcico y tres capas de color superpuestas, sin capa de preparación intermedia entre ellas. Dos de estas capas están compuestas por blanco de zinc y tierra roja; la intermedia es de blanco de plomo y tierra roja. Por la composición del pigmento blanco utilizados en dos de las capas (blanco de zinc - en uso a partir de la segunda mitad del siglo XIX) podemos deducir que las tres son recientes.

El pardo de los cabellos de la Virgen presenta dos policromías:
- La más antigua se ha pintado con tierras, ricas en óxidos de hierro, y blanco de plomo sobre una lámina de oro, aplicada a mixtión (con una base de blanco de plomo y tierras)

- La segunda policromía está compuesta por tres estratos: preparación (de sulfato cálcico), imprimación (con blanco de plomo y minio) y estrato de color, compuesto por tierras, blanco de plomo y calcita.

En los ropajes de la Virgen se han encontrado dos policromías. Como vimos anteriormente, en la parte posterior de la imagen, la última presenta una capa de preparación distinta a la de la parte anterior. La primera es de carbonato cálcico y la segunda de sulfato cálcico; esto es debido a la modificación que sufrió la imagen, en el curso de una restauración.

El manto azul de la Virgen tiene dos policromías:

- La más antigua, está constituida por blanco de plomo y azurita

- La segunda, consta de la capa de preparación (de sulfato cálcico o carbonato cálcico, según la localización), bol rojo, lámina de oro y capa de color, compuesta por blanco de plomo y azul de Prusia.

La peana, que también fue modificada, presenta varias policromías o repintes:

- La más antigua únicamente presenta restos de la preparación y el bol, en la muestra analizada

- Superpuesta a la anterior hay una capa de preparación de sulfato cálcico sobre la que se ha aplicado una nueva preparación, esta vez de carbonato cálcico, y tres capas de color, dos de ellas están compuestas por litopón, tierras y carbón y la última, por sombra tostada, carbón, amarillo de bario y blanco de zinc. Tanto el litopón -en uso desde finales del S.XIX-como el blanco de zinc - en uso a partir de la segunda mitad del siglo XIX- nos dan información de la actualidad de estas capas.

Los pigmentos identificados han sido los siguientes:

Blanco: blanco de plomo, litopón, blanco de zinc

Rojo: bermellón, tierra roja, bol rojo

Azul: azul de Prusia

Amarillo: amarillo de bario

Pardos: sombra tostada, tierras

Negro: carbón animal

Metálicos: oro

\section{ESTADO DE CONSERVACIÓN}

A simple vista, el estado de conservación general de la obra, podía calificarse de regular, ya que no presentaba alteraciones importantes, ni problemas de estabilidad e integridad. 
Con la puesta en marcha del tratamiento y el contacto directo con la talla, se pudo comprobar el estado real de conservación.

Este era particularmente grave a nivel de soporte, el cual, en un principio se pensó que solo presentaba un leve ataque de xilófagos a nivel de la peana.

Con el estudio radiográfico ya se empezaron a vislumbrar algunas diferencias de densidades en forma de galerías y con la limpieza comenzaron a aparecer orificios de salida de considerable tamaño.

Ante la alarmante situación se decidió acceder al interior de la imagen, con lo cual se pudo apreciar en toda su magnitud el estado real de conservación a nivel de soporte.

\section{Principales alteraciones}

Las principales alteraciones detectadas han sido las siguientes:

\section{Soporte}

Es a nivel de este estrato donde se habían producido las mas graves alteraciones.

Lo que en un principio se detectó como un leve ataque de xilófagos, se convirtió en un grave ataque a nivel general y en estado muy avanzado. Por lo que se pudo comprobar y dadas las características del insecto causante, la actividad era nula, pero los destrozos producidos eran muy significativos.

A nivel exterior se han producido pérdidas de soporte producidas por los orificios de salida de los insectos. Estas se localizan principalmente en la zona anterior de la imagen, siendo las mayores en zonas muy visibles, como son el borde superior de la túnica a la altura de la clavícula izquierda y la caída de la misma a nivel del interior de la rodilla del mismo lado. El resto son de menor tamaño pero numerosas, oscilando entre los 2 y $6 \mathrm{~mm}$ de diámetro.

Las mayores pérdidas producidas no eran visibles, habiendo zonas que sólo conservaban una fina capa de madera más los estratos de preparación y policromía o sólo las dos últimas, con el grave riesgo que al menor golpe se hundiera.

Esta patología se acentuaba en las zonas de caída de la túnica y el manto bajo las rodillas y en la cabeza.

Así mismo se han producido pérdidas en la peana tanto en el borde inferior como en la zona donde se alojan los tornillos de sujeción al trono.

El Niño presentaba pérdidas de las últimas falanges de los dedos índice y corazón de la mano derecha y el pajarito situado en la mano derecha de la Virgen, fragmentos de las alas.

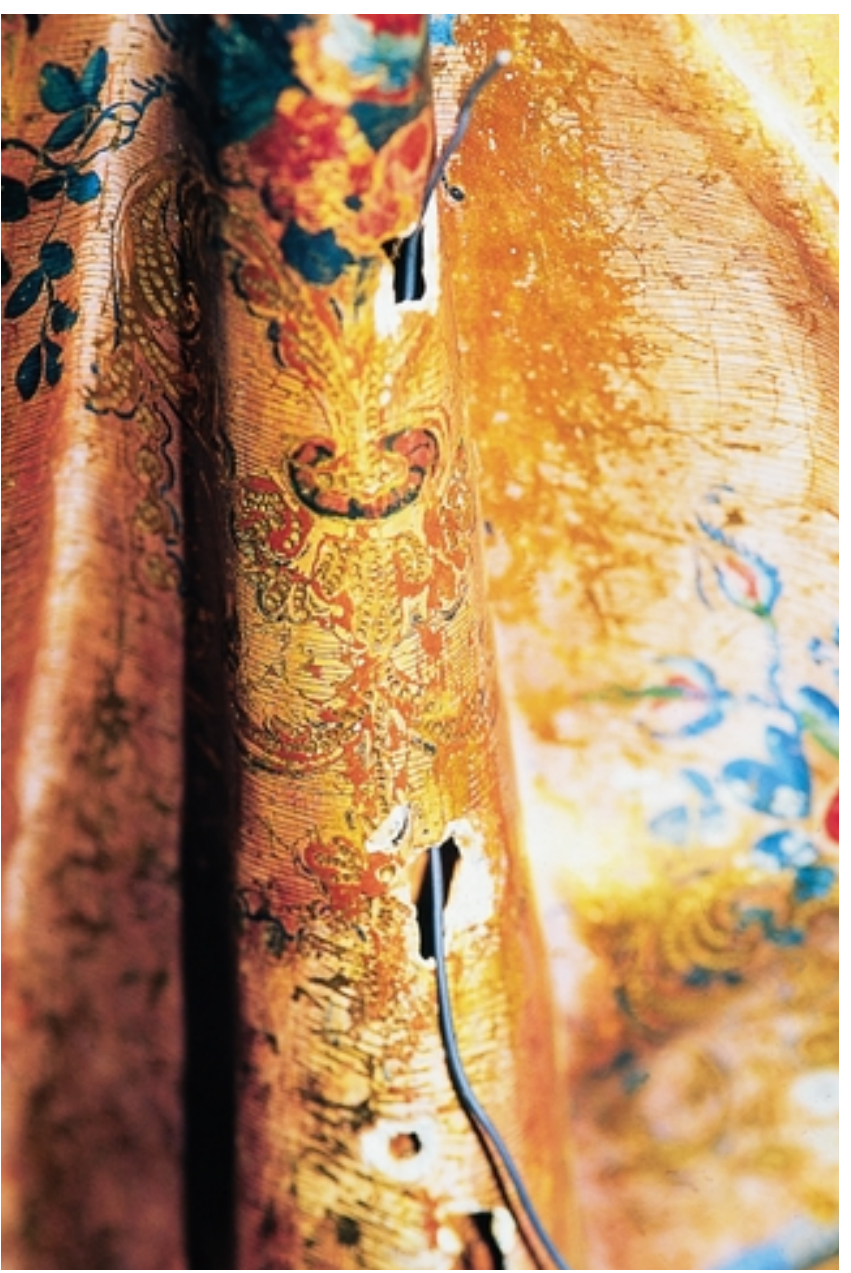

Presentaba numerosas grietas, todas en sentido longitudinal, producidas por los movimientos propios de la madera, no suponiendo peligro alguno para la integridad de la obra.

El sistema de sujeción de las manos evidenciaba cierta holgura, produciendo a la vez daños en la zona circundante de penetración del perno metálico.

Vista la documentación radiográfica se pudo comprobar la gran cantidad de elementos metálicos existentes, de considerables dimensiones, sobretodo en la base, para asegurar la unión de las sucesivas peanas. Asimismo se localizaron también en la unión de la tapa de caoba que cierra el hueco interior y asegurando la unión del Niño con la Virgen.

Las intervenciones mas significativas que se han producido sobre la imagen, a lo largo de su historia material, a nivel de soporte son:

- Eliminación de la corona y retallado de la cabeza.

- Cerramiento del hueco interior y reconstrucción de la zona.

- Cambio del Niño.

- Reintegración de las pérdidas de soporte con duros empastes.

- Adaptación de las manos a un sistema móvil de sujeción.

- Adaptación de dos peanas en distintas épocas.
Orificios de salida insectos, produciendo graves pérdidas de soporte. 
$\frac{\pi}{\infty}$
0
$\sum$
$\Sigma$

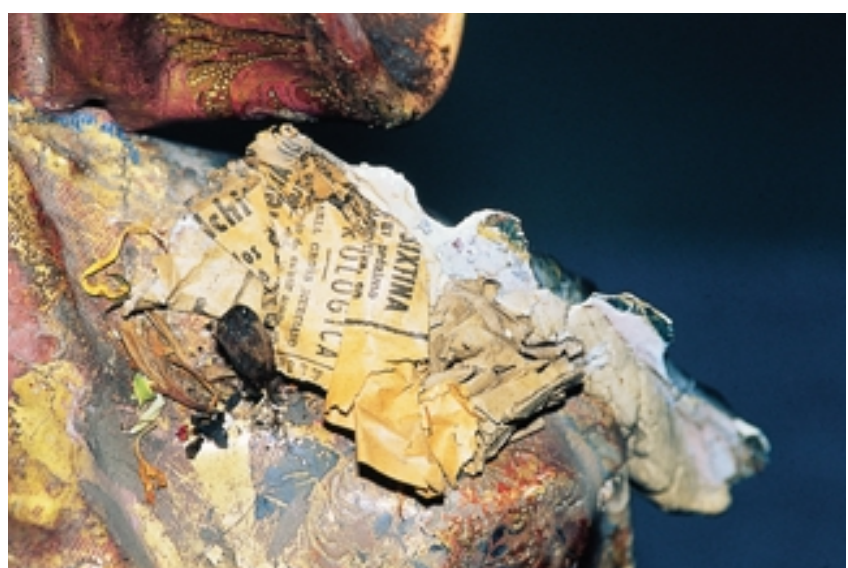

Relleno de yeso y papel para el ajuste del Niño a la Virgen, encontrados durante la intervención y que fueron eliminados

\section{Agentes biodeteriorantes}

Los fenómenos de biodeterioro de la madera son causados por diversos organismos con características metabólicas diferentes. Los principales responsables del biodeterioro de la madera son organismos heterótrofos como hongos, bacterias, actinomicetos e insectos. Pocos de estos agentes de degradación tienen la capacidad de atacar todos los tipos de maderas, debido a su diferente composición química. La resistencia natural de la madera al deterioro se denomina durabilidad, así pues las diferentes especies leñosas pueden ser divididas en clases de durabilidad (G. Caneva, M.P. Nugari y O. Salvadori, 1994).

Se realizó una inspección visual del objeto tomándose distintas muestras de serrín para su posterior observación al estereomicroscopio. La observación y la toma de muestras se ha realizado en el mes de marzo. Se observaron restos de madera y excrementos de insectos xilófagos, lo que nos da una idea del tipo de plaga que está atacando o ha atacado el soporte. En este caso concreto se han identificado como excrementos de Anóbidos, Anobium punctatum De Geer y de un Cerambícido, Hylotrupes bajulus L. o "Capricornio de las casas".

No se pudo obtener ningún insecto adulto sólo una larva de anóbido, aunque debido al mal estado que presentaba no se pudo proceder a su determinación.

Se observaron multitud de orificios y galerias. Los orificios de salida tienen un diámetro de 2-3 mm, sin embargo no se observa ninguno reciente por lo que, por el momento, la plaga no presenta actividad. Las galerías observadas son de un tamaño mucho mayor, por lo que es un dato más para suponer que la imágen fue atacada por una plaga de cerambícidos ( Hylotrupes bajulus L.).

\section{Anobium punctatum De Geer}

Habitat natural. Especie muy común en España y Europa, países de clima templado (N. E. Hickin, 1963). Ataca casi todas las maderas, aún cuando sean viejas y secas, excepto el duramen de roble y algunas ma- deras tropicales (caoba). La humedad favorece su desarrollo y la temperatura óptima es de $22^{\circ} \mathrm{C}$.

Daños causados. Los daños más graves se observan en lugares de mayor humedad y reducida temperatura. Las galerías son numerosas en la zona primaveral de la madera y pueden extenderse a la zona tardía en aquellas maderas en las cuales no se distinguen bien ambas zonas (ej. aliso, haya, abedul, olmo y pícea).

Reconocimiento de los daños. Los orificios de salida son perforaciones redondas de 1 a $6 \mathrm{~mm}$ de diámetro. Cuando se observa el serrín al estereomicroscopio se distinguen unas bolitas elipsoidales o con forma de limón que son los excrementos. Una actividad continua de la plaga se pone de manifiesto por los montoncitos de polvo o serrín y por la aparición de orificios con restos frescos en el verano (S. R, Edwards \& al., 1980).

Hábitos y ciclo de vida. La emancipación de los imagos es continua en primavera hasta fin de verano. La hembra coloca sus huevos, aproximadamente en fisuras o perforaciones de la madera o en los orificios causados por generaciones precedentes. Las larvas no perforan la superficie, por lo que el serrín y excrementos quedan sueltos en las galerías. El imago sale por una perforación redonda. El plazo de generación es muy variable, de 8 meses a 3 años, según las condiciones.

\section{Hylotrupes bajulus L.}

Este insecto es uno de los más peligrosos para la madera seca y uno de los xilófagos más importante y temible.

Habitat natural. La importancia de este xilófago se extiende por toda europa, sobre todo por la zona mediterránea. La madera más frecuentemente atacada es la de coníferas. Para el desarrollo de este insecto es necesario que se den unas condiciones de temperatura alta y que la madera contenga mucha humedad, aunque también puede sobrevivir en madera seca. Con el tiempo disminuye el peligro de ataque, maderas con un siglo de antigüedad normalmente no contienen larvas.

Daños causados. La madera atacada puede ser completamente desintegrada y la extensión de los daños estructurales depende de la importancia de la plaga.

Reconocimiento de los daños. La infestación es fácilmente reconocible. Los orificios de salida tienen forma oval y un diámetro máximo de 6 a 10 mm, pero no siempre son fáciles de observar. Los restos de serrín se acumulan bajo el objeto atacado pero son menos numerosos que en el caso de los anóbidos (Anobium punctatum). Las galerías aparecen cubiertas de fibras de la madera (virutas), serrín y excrementos (J. D. Bletchly, 1967).

Hábitos y ciclo de vida. La hembra coloca sus huevos (200-450) en grandes grupos en grietas de la madera. Las larvas nacen después de unos 10-20 días, entrando 
en la madera perforando galerías de sección elíptica transversal en las cuales el serrín que contienen, mezclado con excrementos cilíndricos, es apretado continuamente por las larvas formando una masa compacta. La larva raramente expulsa el serrín, pero como éste es muy fino, a veces cae al exterior. La larva se alimenta de la madera durante algunos años. Ésta se empupa en una galería cercana a la superficie, tapando ambos lados con serrín y virutas. La fase de pupa dura alrededor de tres semanas y los adultos emergen mediante una perforación elíptica en los días cálidos entre julio y octubre. El plazo de una generación varía mucho entre 2 y 10 años (J. Bernis Mateu, 1974).

No se puede asegurar que el tipo de coleóptero xilófago que estuvo infestando la imágen fuese el anteriormente descrito puesto que no se dispuso de ningún ejemplar para su estudio. Se trata sólo de una hipótesis basada en la forma y tamaño de los excrementos y en el tipo y tamaño de las galerías que se han observado durante la restauración.

\section{Preparación y policromía}

El estado de conservación de ambos estratos podía calificarse de bueno, presentando defectos de adhesión en pequeñas zonas muy localizadas, zonas de desgaste por abrasión en los filos de ambas mangas, y lagunas poco significativas a excepción de aquellas producidas por las propias pérdidas de soporte y las producidas en la zona baja de la peana, producto de la manipulación a la que es sometida en los distintos traslados.

Las intervenciones llevadas a cabo sobre estos estratos han modificado la apariencia externa de la obra dejándole el aspecto que actualmente presenta.

Además de la intervención general se produjeron otras más puntuales en las zonas de desperfectos ocasionados por el ataque de xilófagos.

Estas se centraron en cubrir con gruesas capas de estuco las lagunas ocasionadas por las pérdidas de soporte. Estos gruesos empastes desbordaban sobre el dorado y estofado, produciendo en algunos casos desprendimientos.

Una de las zonas más dañadas, era la de la rodilla izquierda de la Virgen, donde se había superpuesto gran cantidad de yeso mezclado con papel de periódico, para cubrir el espacio dejado entre el Niño y la Virgen, ya que al ser de distintas épocas, la adaptación entre ambos no era correcta.

\section{Capa de protección}

Esta había conferido, a la imagen, un aspecto mas oscuro y amarillento en la zonas de estofados, ya que el rostro y las manos carecían de ella.

Estas zonas de encarnadura, si presentaban un tono grisáceo producido por los depósitos superficiales, acentuándose en la zona del pecho de la Virgen donde éste tono pasaba a un gris muy oscuro, perdiéndose casi totalmente el cromatismo real.

\section{Superposición de película pictórica}

En base a la metodología de estudio de correspondencia se han elaborado fichas de cada una de las microcatas realizadas, así como el registro en video de las más significativas. Las conclusiones de este estudio son las siguientes:

\begin{tabular}{|c|c|c|c|}
\hline LOCALIZACIÓN & 1ª POLICROMÍA & 2 POLICROMÍA & REPINTES \\
\hline CABELLO & $\begin{array}{l}\text { 1. Soporte(madera) } \\
\text { 2. Preparación blanca } \\
\text { 3. Bol rojo } \\
\text { 4. Oro bruñido }\end{array}$ & $\begin{array}{l}\text { 1. Preparación blanca } \\
\text { 2. Aislante } \\
\text { 3. Marrón oscuro }\end{array}$ & 1. Pardo oscuro \\
\hline $\begin{array}{l}\text { ROSTRO Y } \\
\text { CUELLO }\end{array}$ & $\begin{array}{l}\text { 1. Soporte(madera) } \\
\text { 2. Aislante(cola) } \\
\text { 3. Prepración blanca } \\
\text { 4. Aislante(cola) } \\
\text { 5. Carnación rosa pálido }\end{array}$ & $\begin{array}{l}\text { 1. Preparación blanca } \\
\text { 2. Carnación rosa pálido } \\
\text { 3. Depósitos superficiales } \\
\text { manos }\end{array}$ & \\
\hline MANOS & $\begin{array}{l}\text { 1. Soporte(madera) } \\
\text { 2. Preparación balnca } \\
\text { 3. Aislante(cola) } \\
\text { 4. Blanco+pig. rojo } \\
\text { 5. Rosa pálido+pig. rojo } \\
\text { 6. Depósitos superficiales }\end{array}$ & & \\
\hline $\begin{array}{l}\text { TOCA SOBRE } \\
\text { CABEZA }\end{array}$ & $\begin{array}{l}\text { 1. Soprte(madera) } \\
\text { 2. Tela encolada } \\
\text { 3. Aislante(cola) } \\
\text { 4. Preparación blanca } \\
\text { 5. Bol rojo } \\
\text { 6. Oro bruñido } \\
\text { 7. Gris oscuro }\end{array}$ & $\begin{array}{l}\text { 1. Preparación blanca } \\
\text { 2. Bol rojo } \\
\text { 3. Oro bruñido }\end{array}$ & \\
\hline TÚNICA & $\begin{array}{l}\text { 1. Soporte(madera) } \\
\text { 2. Preparación blanca } \\
\text { 3. Bol rojo } \\
\text { 4. Oro bruñido }\end{array}$ & $\begin{array}{l}\text { 1. Preparación blanca+impurezas } \\
\text { 2. Aislante(cola) } \\
\text { 3. Bol rojo } \\
\text { 4. Oro bruñido } \\
\text { 5. Rosa }\end{array}$ & 1. Gris oscuro \\
\hline MANTO & $\begin{array}{l}\text { 1. Soporte(madera) } \\
\text { 2. Preparación blanca } \\
\text { 3. Aislante(cola) } \\
\text { 4. Azul claro }\end{array}$ & $\begin{array}{l}\text { 1. Preparación blanca+impurezas } \\
\text { 2. Aislante(cola) } \\
\text { 3. Bol rojo } \\
\text { 4. Oro bruñido } \\
\text { 5. Azul claro }\end{array}$ & $\begin{array}{l}\text { 1. Preparación blanca } \\
\text { 2. Bol rojo } \\
\text { 3. Oro bruñido } \\
\text { 4. Azul oscuro }\end{array}$ \\
\hline $\begin{array}{l}\text { MANTO } \\
\text { (Zona posterior) }\end{array}$ & & $\begin{array}{l}\text { 1. Soporte (tela encolada) } \\
\text { 2. Preparación blanca+impu- } \\
\text { rezas } \\
\text { 3. Bol rojo } \\
\text { 4. Oro bruñido } \\
\text { 5. Azul claro }\end{array}$ & $\begin{array}{l}\text { 1. Preparación blanca } \\
\text { 2. Bol rojo } \\
\text { 3. Oro bruñido } \\
\text { 4. Azul oscuro }\end{array}$ \\
\hline BASE ORIGINAL & $\begin{array}{l}\text { 1. Soporte(madera) } \\
\text { 2. Preparación blanca } \\
\text { 3. Bol rojo } \\
\text { 4. Oro bruñido } \\
\text { 5. Verde(laca) } \\
\text { 6. Negro, en reborde de las } \\
\text { letras }\end{array}$ & $\begin{array}{l}\text { 1. Preparación blanca+impurezas } \\
\text { 2. Bol rojo } \\
\text { 3. Oro semibruñido } \\
\text { 4. Verde pardo } \\
\text { 5. Negro, en reborde de las letras } \\
\text { 6. Barniz }\end{array}$ & 1. Marrón \\
\hline
\end{tabular}



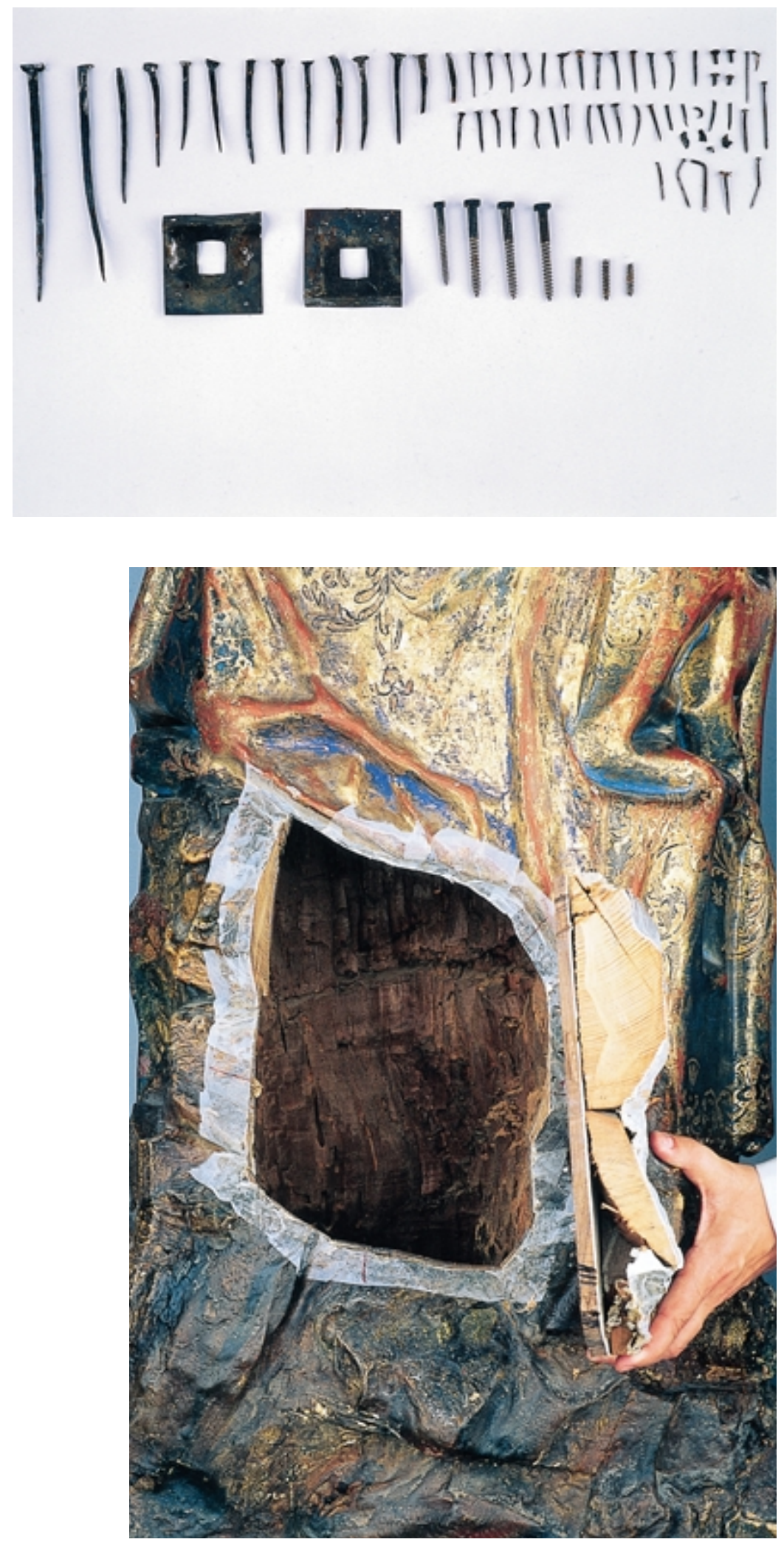

Elementos metálicos extraidos del soporte.

Apertura realizada para acceder al interior de la imagen.

\section{TRATAMIENTO REALIZADO}

El tratamiento realizado en la imagen de Sta. $\mathrm{M}^{\mathrm{a}}$ de la Victoria ha perseguido en todo momento la consolidación de su estructura, a la vez que una correcta presentación estética sin alterar su lectura formal.

\section{Soporte}

En él es donde se ha concentrado la mayor parte del tratamiento, dado su mal estado de conservación.

En primer lugar se eliminaron todos aquellos elementos metálicos a los que pudimos tener acceso y su extracción no suponía un daño mayor al que ejercía el elemento en sí.

La mayor parte de estos estaban localizados en la peana, tanto en el exterior, en el reborde inferior, de donde se extrajeron de forja de pequeño tamaño(I $2 \mathrm{cms}$ ) y fragmentos de tornillos, y en el interior, en la base de la primera peana, de donde se extrajeron los de mayor tamaño ( $15-20 \mathrm{cms})$.

Estos últimos fueron sustituidos por espigas de madera.

Todos los pequeños orificios ocasionados por estas extracciones, fueron resanados e injertados de madera.

Para acceder al interior de la imagen, ya que desclavar la tapa de caoba hubiera supuesto un gran destrozo en esa zona, se decidió cortar por donde se dañara lo menos posible las zonas nobles. Para ello se abrió por la zona de risco realizada en la última transformación que sufrió la Virgen.

La linea superior de apertura se encontraba justo debajo del último pliegue del manto por su parte posterior. La apertura total ocupaba una superficie de $31 \times 2 \mid ' 5 \mathrm{cms}$.

Una vez que se accedió al interior se pudo comprobar el verdadero alcance de los daños ocasionados por los insectos xilófagos.

La primera operación fue la de limpieza de la zona, que se realizó por medio de aspiración, y de las múltiples galerías, las cuales se encontraban llenas de serrín.

Para la eliminación de este serrín se utilizó aire comprimido, dejándolas vacías para recibir el consolidante que se aplicaría posteriormente.

Para facilitar la penetración del desinsectante y consolidante, se practicaron, en la madera visible del interior, unos depósitos, cada $10 \mathrm{cms}$ aproximadamente, de $12 \mathrm{cms}$ de profundidad y $22 \mathrm{~mm}$ de diámetro, con una capacidad de $60 \mathrm{ml}$.

Se utilizó en primer lugar una mezcla líquida, compuesta por un desinsectante a base de permetrina, más paraloid B-72 a un 35\% en diacetonaalcohol como consolidante.

Esta mezcla se fue inyectando en todos los orificios y galerías visibles, y se rellenaron los depósitos para que fueran saturando la madera circundante.

Como segundo consolidante se utilizó una resina epoxídica(araldit-M+endurecedor HY 956) cuya vis- 


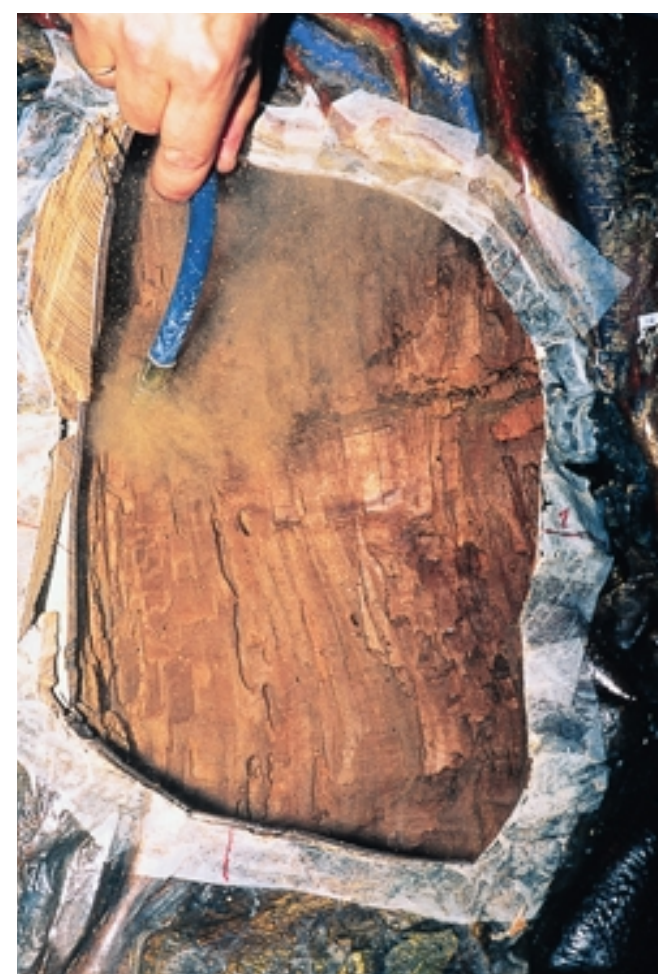

cosidad permitiera un alto poder de penetración y poder llegar y rellenar de material sólido las galerías practicadas por los insectos.

Para conseguir una mayor penetrabilidad se añadió un $80 \%$ de xileno+isopropanol+éter acético $(1: 1: 1)$. Esta proporción se fue disminuyendo hasta cero, conforme se fueron rellenando galerías.

Esta misma operación se realizó por el exterior, utilizando para ello todos los orificios de salida de insectos.

Para el cierre definitivo de galerías se utilizaron injertos de madera y araldit sv 427.

Posteriormente se procedió al cierre de la apertura posterior.

Para el sistema de sujeción de las manos se ha utilizado un sistema de "anclaje rápido" tipo bayoneta. Este consiste en dos piezas complementarias, en acero inoxidable, una maciza de forma cilíndrica embutida en la mano y otra hueca en el antebrazo que aloja a la anterior. El anclaje se ajusta con un muelle interior que asegura la unión mediante presión

Los sistemas de sujeción de las coronas, se han sustituido igualmente por otros en acero inoxidable, consistentes en piezas fijas con rosca interna, en ambas cabezas, en las cuales se alojan pernos roscados que servirán de sujeción. El de sujeción del cetro se ha conservado tal cual, solamente se ha interpuesto entre el metal y la mano un material aislante.

El Niño de ser una pieza fija adaptada a la Virgen, a pasado a ser móvil mediante dos piezas, en el mismo ma-

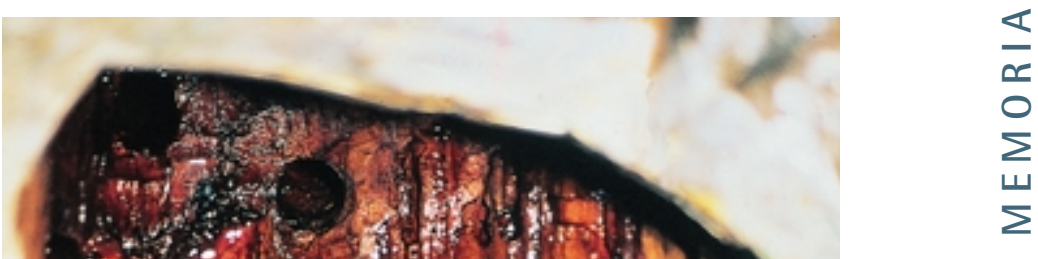

$\frac{1}{\infty}$ 
$\frac{\pi}{0}$
$\vdots$
$\Sigma$
$\Sigma$

Detalle de la plataforma metálica adaptada a la base.

Vista frontal de la imagen tras la restauración

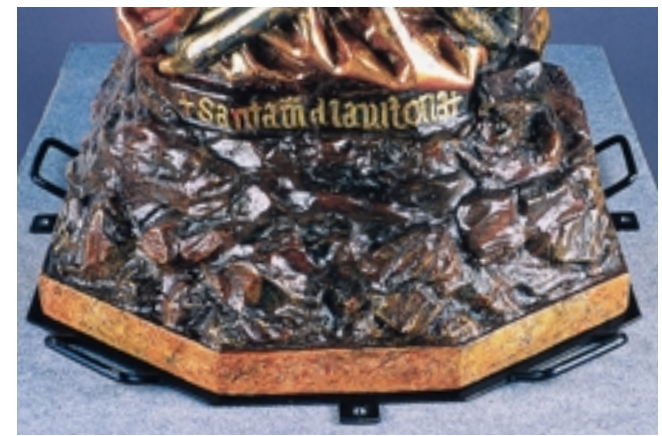

terial que las anteriores, una consistente en un tubo cegado en uno de sus extremos en el cual se adapta perfectamente un perno liso ajustado a la base del Niño.

El relleno de yeso sobre la rodilla de la Virgen, que permitía la adaptación del Niño, fue eliminado y sustituido por otro en araldit sv 427 adaptado a la base del Niño y no a la rodilla de la Virgen, dejándola así exenta de cualquier elemento ajeno.

Para evitar en lo posible la abrasión constante a que era sometida la imagen en los traslados, se ha añadido una plataforma metálica adaptada a la base, con cuatro asas para los traslados y cuatro pletinas salientes del contorno con orificios centrales para la sujeción al trono, con lo cual se anula el primitivo sistema.

\section{Preparación y policromía}

La intervención sobre estos estratos ha consistido fundamentalmente en la fijación de zonas puntuales, la eliminación de estucos y repintes desbordantes sobre el original y la reintegración de lagunas.

Previamente se realizaron los correspondientes exámenes visuales con iluminación natural, ultravioleta y reconocimiento con lupa binocular, para a continuación pasar a los test de limpieza y la elaboración de las fichas con los comportamientos de los diferentes disolventes.

Para la fijación de los levantamientos de estratos se ha empleado como adhesivo "colleta" inyectada, ya que la aplicación a pincel podría desbordar y al eliminar con agua podría dañar el estrato de oro.

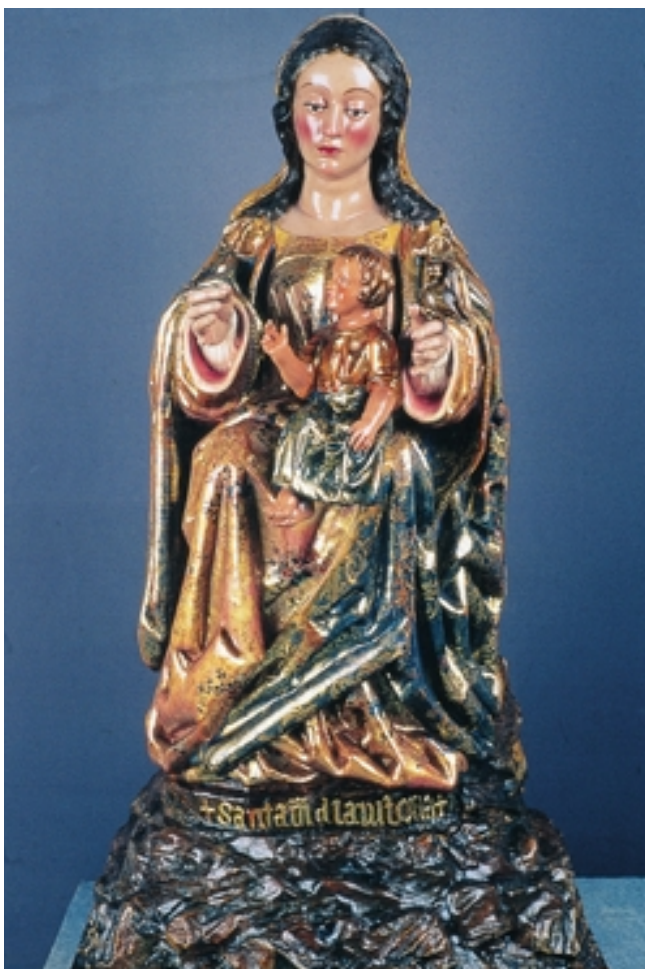

El estuco utilizado para la reintegración de lagunas está compuesto de sulfato cálcico saturado en cola animal diluida en agua.

La reintegración cromática se ha realizado con técnica acuosa, incluso en las zonas de estofado.

\section{Capa de protección}

En primer lugar se ha realizado una limpieza de polvo y depósitos superficiales, para a continuación pasar a un desbarnizado general, empleando los disolventes y técnicas adecuadas, según los test de limpieza efectuados.

Como fase final se ha aplicado una capa protectora, a pincel, sobre la base de color y otra pulverizada sobre la reintegración final. Esta capa ha consistido en una solución de resina sintética en esencia de petróleo.

\section{En la realizacion de los diferentes apartados de este informe han intervenido:}

\section{Estudio histórico-Artístico}

Eva Villanueva Romero

Historiadora del Departamento de Investigación.

Centro de Intervención del IAPH.

Estado de conservación, tratamiento realizado, documentación gráfica y realización de la intervención

Enrique Gutiérrez Carrasquilla

Restaurador del Departamento de Tratamiento.

Centro de Intervención del IAPH.
Documentación fotográfica y radiográfica:

Eugenio Fernández Ruiz

Departamento de Análisis.

Centro de Intervención del IAPH.

Investigación analítica:

Lourdes Martín García

Química del Departamento de Análisis.

Marta Sameño Puerto

Bióloga del Departamento de Análisis.

Centro de Intervención del IAPH. 